\title{
A DNA-Based Coated Wire Membrane Sensor for Selective Determination of Amiloride in Pharmaceutical Compounds, Plasma and Urine
}

\author{
Alireza Allafchian and Ali Asghar Ensafi* \\ Department of Chemistry, Isfahan University of Technology, Isfahan 84156-83111, Iran
}

\begin{abstract}
A construção e características do desempenho de um eletrodo de membrana polimérica baseadas na formação de par iônico para quantificação de amilorida em ds-DNA-amilorida de esperma de salmão são descritas. O filme de ds-DNA-amilorida em esperma de salmão pode ser facilmente preparado como uma camada de cobertura em um eletrodo de fio de platina. Este eletrodo apresenta uma boa resposta potenciométrica para amilorida. As características do desempenho são influenciadas pela composição da membrana e a resposta potenciométrica do eletrodo pode melhorar substancialmente. A melhor performance foi obtida com o eletrodo apresentando uma composição da membrana $(\mathrm{m} / \mathrm{m})$ de $6,4 \%$ de ds-DNA-amilorida como par iônico, $62,9 \%$ de cloreto de polivinila como matriz e $30,7 \%$ de nitrofenil octileter (NPOE) como um íon exclusor. $\mathrm{O}$ eletrodo proposto exibe resposta Nernstiniana no intervalo de concentração de $1,6 \times 10^{-6}$ a $1,0 \times 10^{-2} \mathrm{~mol} \mathrm{~L}^{-1}$ de amilorida com um limite de detecção de $1,5 \times 10^{-6} \mathrm{~mol} \mathrm{~L}^{-1}$ de amilorida e um rápido tempo de resposta, de $5 \mathrm{~s}$. Coeficientes de seletividade para amilorida relativa aos números de substâncias interferentes foram investigados. O sensor foi altamente seletivo para amilorida, em um grande número de compostos. $\mathrm{O}$ uso analítico do eletrodo proposto foi avaliado pela aplicação na determinação de amilorida em amostras reais.
\end{abstract}

Herein, the construction and performance characteristic of a polymeric membrane electrode based on ion-pair formation of salmon sperm ds-DNA-amiloride for quantification of amiloride is described. Salmon sperm ds-DNA-amiloride layer can be prepared easily as a coating layer on a Pt-wire electrode. This electrode has a good potentiometric response to amiloride. The influences of the membrane compositions on the potentiometric response of the electrode have been found to substantially improve the performance characteristics. The best performance was obtained with the electrode having a membrane composition $(\mathrm{m} / \mathrm{m})$ of ds-DNA-amiloride as an ion pair (6.4\%), polyvinyl chloride (PVC) matrix (62.9\%), and 2- nitrophenyl octylether (NPOE) as an ion excluder $(30.7 \%)$. The proposed electrode exhibits Nernstian response in the concentration range of $1.6 \times 10^{-6}$ to $1.0 \times 10^{-2} \mathrm{~mol} \mathrm{~L}^{-1}$ amiloride with a detection limit of $1.5 \times 10^{-6} \mathrm{~mol} \mathrm{~L}^{-1}$ amiloride, performs satisfactorily with a fast response time of $5 \mathrm{~s}$. Selectivity coefficients for amiloride relative to a numbers of potential interfering substances were investigated. The sensor was highly selective for amiloride over a large number of compounds. The analytical usefulness of the proposed electrode has been evaluated by its application in the determination of amiloride in real samples.

Keywords: amiloride determination, ds-DNA modified electrode, potentiometry

\section{Introduction}

Amiloride, 3,5-diamino- $N$-(diaminomethylene)-6chloropyrazinecarboxamide monohydrochloride (Figure 1), is a pyrazinecarbonyl-guanidine derivative, acting as a potassium-sparing diuretic. Administration of amiloride increases urinary excretion of sodium, bicarbonate, and

*e-mail: ensafi@cc.iut.ac.ir calcium with little, if any, increase in chloride excretion. Amiloride is used for its potassium-sparing effect in the treatment or prevention of hypokalemia induced by thiazide or other kaliuretics in patients with congestive heart failure or hypertension. It is a therapeutic drug and a pharmacological tool often used in combination with thiazide diuretics or other kaliuretic-diuretic agents in congestive heart failure or hypertension. Amiloride acts directly on the distal renal tubule of the nephron to inhibit sodium-potassium ion 
exchange. ${ }^{1}$ Administration of amiloride increases urinary excretion of sodium, bicarbonate, and calcium with little, if any, increase in chloride excretion. ${ }^{1}$ Use of amiloride alone or in combination with hydrochlorothiazide has been effective in reducing systolic and diastolic blood pressure.<smiles>NC(N)=NC(=O)c1nc(Cl)c(N)nc1N</smiles>

Figure 1. Structure of amiloride.

It could also be misused in sports involving weight categories to obtain a rapid diminution of weight or to increase the production of urine, which would reduce the concentration and thus the possibility of detection of a urine specimen in drug tests. Amiloride has included it in the list of forbidden substances by the International Olympics Committee, since $1990 .^{2}$ Amiloride is incompletely absorbed and it does not appear to be metabolized. Amiloride in plasma has a half life of 6 to $10 \mathrm{~h}$ and about $50 \%$ of an oral dose is excreted in the unchanged form in urine. $^{3}$

Amiloride has been individually determined in pharmaceutical preparations and biological fluids like urine and plasma using several methods including spectrophotometry, ${ }^{4-7}$ high performance liquid chromatography, ${ }^{8-10}$ fluorimetry, ${ }^{11-13}$ capillary isotachophoresis, ${ }^{14}$ chemiluminescence oxidation, ${ }^{15}$ differential-pulse polarography, ${ }^{16}$ differential-pulse stripping voltammetry, ${ }^{17}$ and potentiometry. ${ }^{18}$

Potentiometric detection based on ion-selective electrodes (ISEs) offers several advantages such as ease of preparation and procedures, simple instrumentation, relatively fast response, wide dynamic range, reasonable selectivity, and low cost. ${ }^{19,20}$ Based of our knowledge, there is not any report for the determination of amiloride based selective electrode using ds-DNA. In this study we have shown that ds-DNA-amiloride layer can be prepared easily as a coating layer on a Pt-wire electrode. The aim of the presented work was to examine further possibilities of the application of the DNA-Amiloride ion-pair system as an electroactive material and NPOE as an anion excluder in PVC matrix for direct analysis of amiloride in human urine, plasma and tablets with potentiometric detection.

\section{Experimental}

Reagents

All chemicals used were of analytical grade quality. The water used was deionized and then passed through a Milli-Q water purification system (resistance $>18 \mathrm{M} \Omega \mathrm{cm}^{-1}$ ).

2-Nitrophenyl-octylether (NPOE) (Aldrich, Cat. No. 365130), PVC of high relative molecular weight (Fluka, Cat. No. 81387), dioctyl phthalate (DOP) (Aldrich, Cat. No. 525154), bis-(2-ethyl-hexyl)sebacate (DOS) (Aldrich, Cat. No. 29083-1), dibutyl phthalate (DBP) (Aldrich, Cat. No. 152439), and tetrahydrofuran (THF) (Aldrich, Cat. No. 360589) were used without further purifications, except THF which was distilled before using.

Tris-HCl (TES) buffer $\mathrm{pH} 7.0$ contained $10.0 \mathrm{mmol} \mathrm{L}^{-1}$ of Tris-HCl (Merck, Cat. No. 108219) plus NaCl (Merck, Cat. No. 106404) plus $1.0 \mathrm{mmol} \mathrm{L}^{-1}$ of EDTA (Merck, Cat. No. 324503).

Double-stranded salmon sperm DNA (Fluka, Cat. No. 31149) and calf-thymus DNA (Sigma, Cat. No. D8515) was used. The Sock solutions, $1000 \mathrm{mg} \mathrm{L}^{-1}$, were prepared by dissolving $5.0 \mathrm{mg}$ of each of the ds-DNA into $5.0 \mathrm{~mL}$ of TES buffer ( $\mathrm{pH}$ 7.0).

An amiloride hydrochloride stock solution, $1.0 \times 10^{-2} \mathrm{~mol} \mathrm{~L}^{-1}$, was prepared by dissolving $0.2661 \mathrm{~g}$ of amiloride hydrochloride (Aldrich, Cat. No. A7410) in water, and the results solution was diluted with water in a $100 \mathrm{~mL}$ volumetric flask. The solution was kept in a dark glass bottle and then stored at $4{ }^{\circ} \mathrm{C}$. More dilute solutions of amiloride hydrochloride were prepared daily by accurate dilution of the stock solution with water.

Urine samples were obtained from fasting healthy people during morning hours.

\section{Sample pretreatment}

Commercial pharmaceutical preparations of two different brands were assayed. A portion of each powder (40-60 mg) were accurately weighed and transferred to $50 \mathrm{~mL}$ volumetric flasks using $25 \mathrm{~mL}$ of $\mathrm{H}_{2} \mathrm{O}$. The flasks were mechanically shaken for $30 \mathrm{~min}$, completed to the mark with water, mixed and left for $30 \mathrm{~min}$ at room temperature to decant the solids. Then, $1.0 \mathrm{~mL}$ aliquot were transferred from each flask to $25 \mathrm{~mL}$ volumetric flasks and diluted to the mark with water.

The sample of human urine was diluted 10 times and spiked with stock solution of amiloride to get the final concentrations of amiloride (between $1.0 \times 10^{-4}$ and $\left.1.0 \times 10^{-2} \mathrm{~mol} \mathrm{~L}^{-1}\right)$ in 10 times diluted urine. The samples were spiked just before analysis.

\section{Apparatus}

Potentials were measured by direct potentiometry with a cell assembly as follow: 
$\mathrm{Hg} / \mathrm{Hg}_{2} \mathrm{Cl}_{2}, \mathrm{KCl}$ (sat'd)| |Amiloride solution | Membrane | Pt-wire

All potentiometric measurements were made at $25 \pm 1{ }^{\circ} \mathrm{C}$ in a $5 \mathrm{~mL}$ double walled glass cell with a constant magnetic stirring with a Corning digital ion analyzer, Model $140 \mathrm{pH} / \mathrm{mV}$, using a saturated calomel reference electrode in conjunction with the proposed amiloride sensor. Response times were determined after the potential of the solution had became constant, and similar measurements were carried out in another solution of 100 -fold lower concentration. A Corning glass electrode conjugated with $\mathrm{Ag} / \mathrm{AgCl}$ reference electrode, Model 6.0232.100, was used to check the $\mathrm{pH}$ of the solutions.

IR spectra were recorded using FT-IR (Jasco, 680 plus) with a resolution of $1.0 \mathrm{~cm}^{-1}$.

\section{Electrode preparation}

The membrane was made by the following procedure: $25.0 \mathrm{~mL}$ of $1.0 \times 10^{-2} \mathrm{~mol} \mathrm{~L}^{-1}$ aqueous amiloride solution was added to $25 \mathrm{~mL}$ of $1000 \mathrm{mg} \mathrm{L}^{-1}$ solution of the ds-DNA in Tris buffer at $\mathrm{pH}$ 7.0. The resulting yellow precipitate was filtered and washed with deionized water and dried, protected from light in a dissector at room temperature. Then, about $2.6 \mathrm{mg}$ of the precipitate (salmon sperm ds-DNA-amiloride) was mixed with $12.5 \mathrm{mg} \mathrm{PVC}$ and $25.6 \mathrm{mg}$ NPOE previously was mixed with $1 \mathrm{~mL}$ of THF to produce suspension solution after mixing the mixture for $15 \mathrm{~min}$ with shaking the mixture. Then the mixture was filtered and the filtered solution was used for the electrode preparation. The coating process of the platinum wire electrode was performed by dipping $1.5 \mathrm{~cm}$ of a Pt-wire fifty times into this mixture. After each coating, the membrane was dried with a stream of nitrogen till a thin film was formed. The electrode was finally conditioned for $3 \mathrm{~h}$ in a $1.0 \times 10^{-3} \mathrm{~mol} \mathrm{~L}^{-1}$ of amiloride solution. The sensor has lifetime of 8 days when it was conditioned for $5 \mathrm{~min}$ before using (by soaking in a $1.0 \times 10^{-3} \mathrm{~mol} \mathrm{~L}^{-1}$ amiloride solution for 5 minutes) and stored in air when not in use.

\section{Results and Discussion}

\section{Formation of amiloride-ds-DNA ion pair}

Salmon sperm ds-DNA can makes an insoluble ion pair compound with amiloride with a suitable grain size. Therefore, PVC was used as a polymer matrix to fabricate the membrane sensors. The ion association complex of amiloride with the ds-DNA was proved by IR spectra (Figure 2). The IR spectra of amiloride showed two bands of $\mathrm{C}=\mathrm{N}$ at 1696 and $1549 \mathrm{~cm}^{-1}$, whereas for the ion-pair showed at 1686 and $1539 \mathrm{~cm}^{-1}$, respectively. On the other hand the $-\mathrm{NH}_{2}$ band for the ion-pair was sharper than for amiloride. In addition the amide spectra for amiloride appear at $1696 \mathrm{~cm}^{-1}$, whereas for the ion-pair appeared at $1686 \mathrm{~cm}^{-1}$. This means that amiloride has a strong interaction with the ds-DNA.
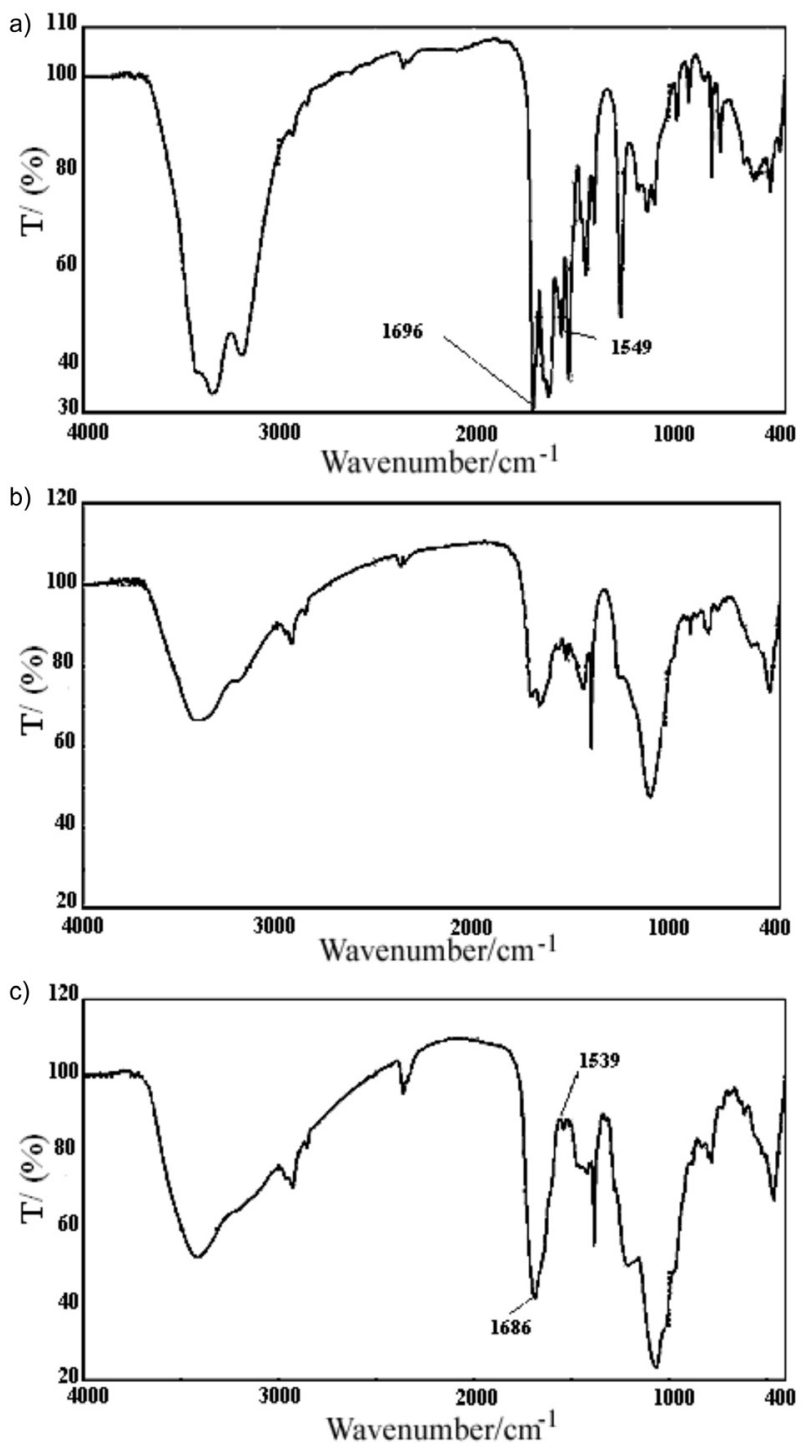

Figure 2. IR spectra of (a) Amiloride; (b) ds-DNA; and (c) The ion association complex.

\section{Influence of membrane composition}

A number of characteristics are required for a sensor to be considered as a suitable sensor for determination of a substance, including selectivity, response time, response range, and sensitivity. The behavior of ion-selective electrodes with solid-state membranes depends on the composition of membrane material used and the condition of the membrane surface in contact with the solution in 
which the activity of sensed ion is monitored. Preliminary experiments were carried out to obtain an optimum membrane composition. The optimized membrane was used to test the performance of the membrane characteristics. In a preliminary experiment, we have constructed two different membranes, with and without the carrier. The results showed that the membrane with no carrier displayed insignificant selectivity and response sensitivity toward amiloride. On the other hand, the membrane containing the ion-pair (salmon sperm ds-DNA-amiloride) showed Nernstian response and remarkable selectivity for amiloride. The results confirm that the interactions of the other substances with the amiloride-ds-DNA layer are insufficient to give a Nernstian response. The preferential response of the membrane toward amiloride is believed to be associated with the interaction of amiloride with the ion-pair.

Since the selectivity, linearity and sensitivity obtained for a given ion-carrier depends significantly on the membrane ingredients, nature of solvent mediators (plasticizer) and additives used, ${ }^{21,22}$ we investigated the influence of membrane composition on the potential response of the amiloride sensor. In addition, it is well known that the construction of PVC based ISEs required the use of a plasticizer which acts as a fluidizer allowing homogenous dissolution and diffusion mobility of the ionpair inside the membrane. The potentiometric response of the membrane was improved in the presence of the several solvent mediators such as NPOE, DBP, DOP and DOS. The results showed that the amiloride selective electrode based on NPOE exhibits a longer linear response according to the amiloride concentration $\left(1.6 \times 10^{-6}\right.$ to $1.0 \times 10^{-2} \mathrm{~mol} \mathrm{~L}^{-1}$ of amiloride) than DBP, DOP and DOS (with concentration range $1.0 \times 10^{-4}$ to $1.0 \times 10^{-2} \mathrm{~mol} \mathrm{~L}^{-1}$ of amiloride) The results are given in Table 1. Therefore, NPOE was chosen as a suitable plasticizer in the rest of experiments.
Subsequently, different membranes composition was checked for the electrode response (Table 1).

With the optimized conditions, the potentiometric response of the membrane was investigated for the electrodes those prepared with two different kind of ds-DNA including salmon sperm ds-DNA and calf thymus ds-DNA. The results showed that the amiloride selective electrode based on salmon sperm ds-DNA exhibits a better Nernstian slope $\left(35.3 \pm 1.0 \mathrm{mV}\right.$ decade $\left.^{-1}\right)$ than that made of calf thymus ds-DNA (with slopes of $12.0 \pm 1.1$ ). Therefore, salmon sperm ds-DNA was chosen to prepare the ion-pair in the rest of experiments. It was obtained that the membrane with a composition of $30.7 \%$ PVC, $62.9 \%$ NPOE and $6.4 \%$ of the ion-pair generated a stable potential response after conditioning for 5 minute in a $1.0 \times 10^{-3} \mathrm{~mol} \mathrm{~L}^{-1}$ amiloride solution.

\section{pH effect}

The $\mathrm{pH}$ dependence of the potentials of the proposed electrode for $1.0 \times 10^{-3} \mathrm{~mol} \mathrm{~L}^{-1}$ amiloride solution was investigated in acidic, basic and neutral solutions. Hydrochloric acid $\left(0.10 \mathrm{~mol} \mathrm{~L}^{-1}\right)$ and/or sodium hydroxide solution $\left(0.10 \mathrm{~mol} \mathrm{~L}^{-1}\right)$ were used to adjust the $\mathrm{pH}$ of the solution. The results (Figure 3 ) showed that the potential of the sensor remains constant from $\mathrm{pH}$ of 2.0 to 7.0. For the solution with more acidic conditions, amiloride may be protonated. On the other hand, in basic $\mathrm{pH}$, hydroxide ions may react with amiloride to produce neutral species, which could not extract into the membrane.

\section{Response time, reproducibility and lifetime}

The response time is an important factor for any ionselective electrode. The response time for the electrode to reach the final equilibrium value was different in different

Table 1. The potentiometric response of the membrane in the presence of the several solvent mediators

\begin{tabular}{|c|c|c|c|c|c|c|}
\hline \multirow[t]{2}{*}{ No. } & \multicolumn{3}{|c|}{ Composition / (\%) } & \multirow{2}{*}{$\begin{array}{c}\text { Slope / } \\
\left(\mathrm{mV} \text { decade }^{-1}\right)\end{array}$} & \multirow[t]{2}{*}{ Dynamic range / $\left(\mathrm{mol} \mathrm{L}^{-1}\right)$} & \multirow[t]{2}{*}{$\mathrm{R}^{2}$} \\
\hline & $\mathrm{PVC}$ & Ion pair & Plasticizer & & & \\
\hline 1 & 31.0 & 7.1 & 61.9, NPOE & -34.7 & $1.0 \times 10^{-2}-6.3 \times 10^{-5}$ & 0.998 \\
\hline 2 & 30.7 & 6.4 & $62.9, \mathrm{DBP}$ & -25.0 & $1.0 \times 10^{-2}-1.0 \times 10^{-4}$ & 0.838 \\
\hline 3 & 30.7 & 6.4 & 62.9, DOS & -28.5 & $1.0 \times 10^{-2}-1.0 \times 10^{-4}$ & 0.888 \\
\hline 4 & 30.7 & 6.4 & $62.9, \mathrm{DOP}$ & -25.6 & $1.0 \times 10^{-2}-1.0 \times 10^{-4}$ & 0.882 \\
\hline 5 & 30.7 & 6.4 & $62.9, \mathrm{NPOE}$ & -35.3 & $1.0 \times 10^{-2}-1.6 \times 10^{-6}$ & 0.999 \\
\hline 6 & 31.8 & 3.0 & $65.2, \mathrm{NPOE}$ & -31.8 & $1.0 \times 10^{-2}-3.1 \times 10^{-5}$ & 0.901 \\
\hline 7 & 32.6 & 2.0 & 65.4, NPOE & -30.3 & $1.0 \times 10^{-2}-1.6 \times 10^{-4}$ & 0.848 \\
\hline 8 & 34.7 & 1.0 & $64.3, \mathrm{NPOE}$ & -27.3 & $1.0 \times 10^{-2}-4.2 \times 10^{-5}$ & 0.791 \\
\hline 9 & 34.0 & --- & $66.0, \mathrm{NPOE}$ & --- & --- & --- \\
\hline
\end{tabular}




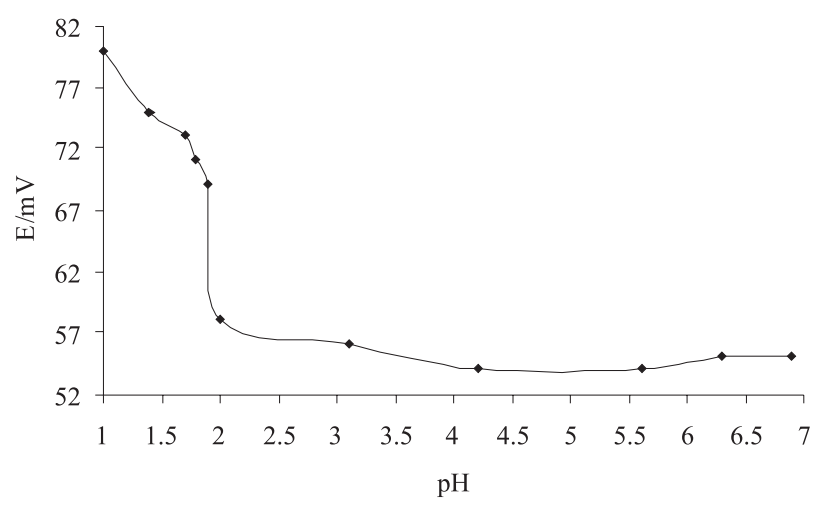

Figure 3. Influence of $\mathrm{pH}$ on the response of the membrane $\left(1.0 \times 10^{-3} \mathrm{~mol} \mathrm{~L}^{-1}\right.$ amiloride $)$.

concentrations. The response time was recorded at different concentrations of amiloride in the sample solution. The potentiometric response of sensors was recorded by changing the solution from lower $\left(1.6 \times 10^{-6} \mathrm{~mol} \mathrm{~L}^{-1}\right.$ amiloride) to higher concentration $\left(1.0 \times 10^{-2} \mathrm{~mol} \mathrm{~L}^{-1}\right.$ amiloride). As can be seen in Figure 4, the response time of the sensors (that is equal to $95 \%$ of its maximum value) was found to be less than $5 \mathrm{~s}$ for various concentrations of amiloride. However, to reach the final equilibrium, the system needs at least $25 \mathrm{~s}$ as a response time. Therefore, there is a little drift for the response signal of the sensor before $25 \mathrm{~s}$. In addition, the response time of the electrode remains stable for several days without much drift in potentials.

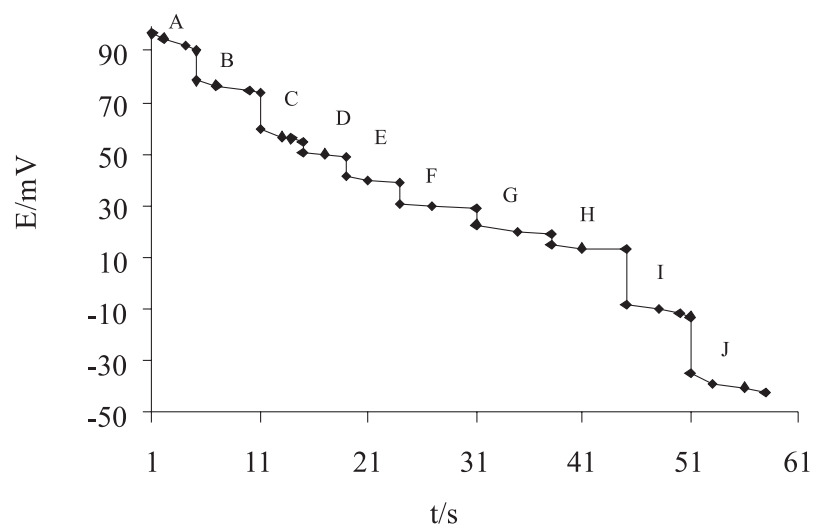

Figure 4. Response time of the electrode under the optimum conditions. A) $1.0 \times 10^{-2}$; B) $3.2 \times 10^{-3}$; C) $1.0 \times 10^{-3}$; D) $6.3 \times 10^{-4}$; E) $3.2 \times 10^{-4}$; F) 1.6 $\times 10^{-4}$; G) $1.0 \times 10^{-4}$; H) $6.3 \times 10^{-5}$; I) $1.0 \times 10^{-5}$; and J) $1.6 \times 10^{-6} \mathrm{~mol} \mathrm{~L}^{-1}$ amiloride.

The electrode potentials were reproducible, and the standards deviation of ten replicated measurements was $\pm 1.0 \mathrm{mV}$ at various concentrations of amiloride. In terms of lifetime, these electrodes gave stable potentials over the period of 8 days without any significant divergence in their Nernstian behaviors. The results are given in Table 2.
Table 2. Response of the sensor during 8 days

\begin{tabular}{lccc}
\hline time / day & $\begin{array}{c}\text { Slope / } \\
\left(\mathrm{mV} \mathrm{decade}^{-1}\right)\end{array}$ & $\begin{array}{c}\text { Dynamic range / } \\
\left(\mathrm{mol} \mathrm{L}^{-1}\right)\end{array}$ & $\begin{array}{c}\text { Detection limit / } \\
\left(\mathrm{mol} \mathrm{L}^{-1}\right)\end{array}$ \\
\hline 1 & $-35.3 \pm 0.1$ & $1.6 \times 10^{-6}-1.0 \times 10^{-2}$ & $1.5 \times 10^{-6}$ \\
2 & $-35.3 \pm 0.1$ & $1.6 \times 10^{-6}-1.0 \times 10^{-2}$ & $1.5 \times 10^{-6}$ \\
3 & $-35.3 \pm 0.1$ & $1.6 \times 10^{-6}-1.0 \times 10^{-2}$ & $1.5 \times 10^{-6}$ \\
4 & $-35.3 \pm 0.1$ & $1.6 \times 10^{-6}-1.0 \times 10^{-2}$ & $1.5 \times 10^{-6}$ \\
5 & $-35.3 \pm 0.1$ & $1.6 \times 10^{-6}-1.0 \times 10^{-2}$ & $1.5 \times 10^{-6}$ \\
6 & $-35.3 \pm 0.1$ & $1.6 \times 10^{-6}-1.0 \times 10^{-2}$ & $1.5 \times 10^{-6}$ \\
7 & $-35.2 \pm 0.1$ & $1.6 \times 10^{-6}-1.0 \times 10^{-2}$ & $1.8 \times 10^{-6}$ \\
8 & $-35.1 \pm 0.1$ & $1.6 \times 10^{-6}-1.0 \times 10^{-2}$ & $2.1 \times 10^{-6}$ \\
\hline
\end{tabular}

The reproducibility and response stability of the sensor were also tested. The standard deviation of slope of the calibration for 10 replicate measurements for amiloride concentrations of $1.0 \times 10^{-3}$ and $1.0 \times 10^{-4} \mathrm{~mol} \mathrm{~L}^{-1} \mathrm{was} \pm 1.02$ and $\pm 1.04 \mathrm{mV}$, respectively.

The critical response characteristic of the proposed electrode was investigated according to IUPAC recommendations. ${ }^{23,24}$ The Pt-coated wire electrode with the optimum composition showed a linear Nernstian response of $\mathrm{E}(\mathrm{mV}) v s$. $-\log$ [Amiloride] with a slope of $35.3 \pm 1.0 \mathrm{mV}$ per decade over the concentration range of $1.6 \times 10^{-6}$ to $1.0 \times 10^{-2} \mathrm{~mol} \mathrm{~L}^{-1}$ of amiloride with a correlation coefficient of $0.998(n=8)$. The limit of detection, which is evaluated according to IUPAC recommendations, ${ }^{25}$ was $1.5 \times 10^{-6} \mathrm{~mol} \mathrm{~L}^{-1}$ of amiloride as shown in Figure 5 .

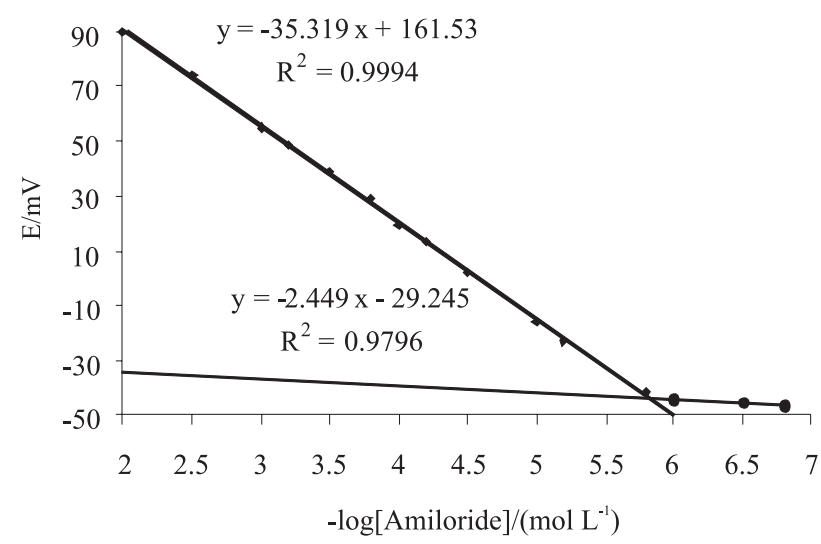

Figure 5. Relation between the electrode potential with $\log$ [Amiloride].

\section{Potentiometric selectivity}

The most important characteristic of a sensor is the selectivity. Many methods have been developed to determine the potentiometric selectivity coefficients. ${ }^{26}$ They measure changes of potential in the presence of two substances simultaneously, the principal and the interfering 
Table 3. Values of selectivity coefficients of amiloride-selective electrode

\begin{tabular}{|c|c|c|c|c|c|c|c|}
\hline Interfering ion & $\log K$ & Interfering ion & $\log K$ & Interfering ion & $\log K$ & Interfering ion & $\log K$ \\
\hline $\mathrm{Na}^{+}$ & -13.81 & $\mathrm{Cs}^{+}$ & -19.73 & Citric acid & -10.21 & Lactose & -4.34 \\
\hline $\mathrm{Ba}^{2+}$ & -14.68 & $\mathrm{Fe}^{3+}$ & -6.02 & Fructose & -6.59 & Glucose & -6.00 \\
\hline $\mathrm{K}^{+}$ & -13.10 & $\mathrm{SO}_{4}^{2-}$ & -21.78 & Sucrose & -5.29 & Phenylanaline & -10.02 \\
\hline
\end{tabular}

substance. Depending on the ligand structure and cation size, complex (or ion-pair) formation or extractability is the determining factor for selectivity. ${ }^{27}$ In this work, the selectivity coefficients of the sensor toward different species were evaluated by using separate solution method (SSM) with a fixed concentration of interference compounds at $1.0 \times 10^{-3} \mathrm{~mol} \mathrm{~L}^{-1}$ at $\mathrm{pH}$ 7.0. The selectivity coefficient values of the electrodes reflect a high selectivity of these electrodes towards amiloride. The results are listed in Table 3. It is obvious from the selectivity coefficient data that alkali metals, alkali-earth metals and heavy metal ions plus several organic compounds give no significant interference in the process of the sensors. The proposed sensor is more selective to amiloride relation to inorganic metal ions than the previous reported method. ${ }^{18}$ This is due to the fact that the new compound, ds-DNA-amiloride, is more hydrophobic than that sodium amiloridetetraphenyl phthalate. As can be seen most of the selectivity coefficients of the potential interfering substances are low, indicating no significant interference in the performance of the electrode.

\section{Analytical applications}

To asses the applicability of proposed sensor in real samples an attempt was made to determine amiloride in real samples such as tablets, urine and plasma. The results are given in Tables 4 and 5. Each sample was analyzed in triplicate by standard addition, using the sensor. The results show that the amount of amiloride recovered with the help of the electrode is good, thereby reflecting the utility of the proposed sensor.

Table 4. Recovery of amiloride in urine and plasma

\begin{tabular}{lccc}
\hline Sample & $\begin{array}{c}\text { Amiloride added / } \\
\left(\mathrm{mmol} \mathrm{mL}^{-1}\right)\end{array}$ & $\begin{array}{c}\text { Amiloride found / } \\
\left(\mathrm{mmol} \mathrm{mL}^{-1}\right)\end{array}$ & $\begin{array}{c}\text { Recovery / } \\
(\%)\end{array}$ \\
\hline Urine & --- & $<\mathrm{LOD}^{*}$ & --- \\
& $1.00 \times 10^{-2}$ & $1.05( \pm 0.08) \times 10^{-2}$ & 105.0 \\
& $1.00 \times 10^{-4}$ & $1.12( \pm 0.09) \times 10^{-4}$ & 112.0 \\
Plasma & --- & $<\mathrm{LOD}^{*}$ & --- \\
& $1.00 \times 10^{-2}$ & $1.09( \pm 0.09) \times 10^{-2}$ & 109.0 \\
& $1.00 \times 10^{-4}$ & $1.13( \pm 0.10) \times 10^{-4}$ & 113.0 \\
\hline
\end{tabular}

*Less than limit of detection. \pm Average of 3 measurements.
Table 5. Determination of amiloride in pharmaceutical samples

\begin{tabular}{lccc}
\hline Tablet & Amiloride / mg & $\begin{array}{c}\text { Amiloride } \\
\text { (found) }\end{array}$ & Recovery / (\%) \\
\hline Amiloride citrate & 10.00 & $10.08 \pm 0.07$ & 100.1 \\
Amiloride & 10.00 & $9.55 \pm 0.52$ & 95.5 \\
\hline
\end{tabular}

\pm Average of three replicates analysis.

\section{Conclusions}

The ion-pair of amiloride-ds-DNA is successfully exploited to be used as a neutral carrier in PVC membrane as a coated wire, and it is revealed near-Nernstian response over a wide concentration range for amiloride. The electrode is very easy to prepare and use. Meanwhile, it also has some other advantages, such as wide dynamic range, fine selectivity and long lifetime in compare to the other ds-DNA based methods. The characters make us believe that this electrode will be used widely. The comparison between the proposed ionophore in this membrane selective electrode indicated that the presented electrode is invariably superior in terms of selectivity over other substances. The detection limit for amiloride is low when compared with other potentiometric sensors.

The sensor is rapid and sensitive enough to be used for measuring amiloride content in pharmaceutical samples.

\section{Acknowledgments}

The authors express their appreciation to the Isfahan University of Technology Research Councils and Center of Excellence in Sensors and Green Chemistry for financial support of this work.

\section{References}

1. Mcevory, G. K.; AHFS Drug Information, American Society of Hospital Pharmacists: Bethesda, M.D., 1990, p. 1481.

2. Riguez Bueno, C.; Dopaje, Interamericana, McGraw-Hill: Madrid, 1992, p. 65.

3. Moffat, A. C.; Clarke's Isolation and Identification of Drugs, Pharmaceutical Press: London, 1986, p. 339. 
4. Orga-Barrales, P.; Pelerano, G.; Vazques, A. A.; Molina-Dia, A.; Anal. Lett. 2002, 35, 1491.

5. Ferraro, M. C. F.; Castellano, P. M.; Kaufman, T. S.; J. Pharm. Biomed. Anal. 2001, 26, 443.

6. Lapa, R. A. S.; Lima, J. L. F. C.; Santos, J. L. M.; Anal. Chim. Acta 2000, 407, 225.

7. Kartal, M.; Erk, N.; J. Pharm. Biomed. Anal. 1999, 19, 477.

8. Reeuwijk, H. J. E. M.; Tjaden, U. R.; Vandergreef, J.; J. Chromatogr. Biomed. Appl. 1992, 575, 269.

9. Bi, H. G.; Cooper, S. F.; Cote, M. G.; J. Chromatogr. Biomed. Appl. 1992, 582, 93.

10. El-Gindy, A.; Emara, S.; Mostafa, A.; Il Farmaco 2005, 60, 269.

11. Dominguez-Vidal, A.; Ortega-Barrales, P.; Molina-Diaz, A.; Talanta 2002, 56, 1005.

12. Pulgarin, J. A. M.; Molina, A. A.; Lopez, P. F.; Anal. Biochem. 2001, 292, 59.

13. Pulgarin, J. A. M.; Molina, A. A.; Lopez, P. F.; Anal. Chim. Acta 2001, 449, 179.

14. Sadecka, J.; Polonsky, J. ; J. Chromatogr., A 1996, 735, 403.

15. Halvatzis, S. A.; Mihalatos, A. M.; Palilis, L. P.; Calokerinos, A. C.; Anal. Chim. Acta 1994, 290, 172.

16. Martin, M. E.; Hernandez, O. M.; Jimenez, A. I.; Arias, J. J.; Jimenez, F.; Anal. Chim. Acta 1999, 381, 247.
17. El-Hefnawy, G. B.; El-Hallag, I. S.; Ghoneim, E. M.; Ghoneim, M. M.; J. Pharm. Biomed. Anal. 2004, 34, 899.

18. Ensafi, A. A.; Allafchian, A. R.; J. Pharm. Biomed. Anal. 2008, 47, 802.

19. Buhlmann, P.; Pretsch, E.; Bakker, E.; Chem. Rev. 1998, 98, 1593.

20. Buck, R. P.; Cosofret, V. V.; Pure Appl. Chem. 1993, 65, 1849.

21. Wahbi, A. A. M; Bedair, M. M.; Galal, S. M.; Gazy, A. A.; Pharm. Sci. 1983, 3, 182.

22. Garcı Sanchez, F.; Fernandez Gutierrez, A.; Cruces Blanco, C.; Anal. Chim. Acta 1995, 306, 313.

23. Huclova, J.; Satinsky, D.; Pavlicek, O.; Vedralova, A.; Karlicek, R.; Anal. Chim. Acta 2006, 573, 376.

24. Pulgarín, J. A. M.; Molina, A. A.; López, P. F.; Anal. Biochem. 2001, 292, 59.

25. Gadzekpo, P. Y.; Christain, G. D.; Anal. Chim. Acta 1984, 167, 279.

26. Umezawa, Y.; Umezawa, K.; Sato, H.; Pure Appl. Chem. 1995, $67,507$.

27. Gupta, V. K.; Singh, A. K.; Al Khayat, M.; Gupta, B.; Anal. Chim. Acta 2007, 590, 81. 